\title{
THE LOCAL WISDOM OF KUBU RAYA SOCIETY AND THE IMPLEMENTATION IN SCIENCE LEARNING
}

\author{
Hairida, Fitria Arifiyanti, Vientinny Safrilianti, Deby Erwinda, Sri Apriliani, Apricilia Ahmadiyah \\ Universitas Tanjungpura, Pontianak, Indonesia \\ E-mail: hairida@fkip.untan.ac.id
}

\begin{abstract}
Local wisdom of an area is important to be preserved so that the values contained in it can be learned and understood by the younger generation. This study aimed to identify the local wisdom of the society of Kubu Raya Regency, especially those who use peatlands for livelihoods. The results of this identification are associated with the Basic Competencies (KD) of Science Subjects of Junior High School (SMP) in the 2013 curriculum. The subjects of this study were 10 science teachers who teach in Kubu Raya Regency and the society who use peatlands for livelihoods with a purposive sampling technique. Descriptive research methods are used to achieve research objectives. Data collection techniques using observation sheets, interviews, and questionnaires. Research results on the local wisdom of the society of Kubu Raya Regency relating to peatlands were 7 (seven) KD for 7 th grade, 2 (two) KD for 8th grade, and 1 (one) KD for 9th grade, science concepts and character values in each KD. Based on expert validation, it can be concluded that there was a match between local wisdom and $\mathrm{KD}$, the concept of Sciences and character values in science subjects of the 2013 curriculum.
\end{abstract}

Keywords: Local Wisdom; Basic Competencies; Learning Tools; Science

\section{INTRODUCTION}

The decline in the character values of the Indonesian people, marked by rampant corruption, drug abuse, sexual violence, is very alarming for the Indonesian people. The efforts made by the government to overcome various problems related to the decline in the nation's character is to prioritize the development of national character in the National Long-Term Development Plan 2005-2025 in order to realize the vision of national development. Thus all efforts made by the Indonesian people are related to the development of national character.

In connection with the development of student character, the government uses the nation's character building strategy through education. Education is believed to have an important role in solving the problem of the weak character of the nation (Alawiyah, 2012). The weak character of the Indonesian nation has become a reality in the life of the Indonesian people today. According to Listyarti (2012), the weak character of the Indonesian people is to underestimate the quality, like to cross over, have no self-confidence, have no discipline, ignore responsibility, hypocrite, lack creativity, bad work ethic, like feudalism, and have no shame. Courtesy, tolerance, solidarity, social care, mutual cooperation, hard work and the like are replaced by suspicion, selfishness, anarchism and the like (Masrukhi, 2012). Character education is needed to reach people who have integrity in moral values. The role of educators is needed in shaping the character of students (Dirgantoro, 2016). But the expected character building through national education has not been optimally implemented in life.

The enactment of the 2013 curriculum shows that the government has tried to overcome the student's character problems. This is demonstrated by the existence of both vertical and horizontal integration between subjects and levels of education, as well as integration between the cognitive, affective, and psychomotor domains. The objectives of the 2013 curriculum are not just about how to make students become smart, but the 2013 curriculum is oriented towards the development of student characters so that it is able to make students have good characters. Thus in learning must be instilled an attitude to develop the character of students.

Learning science will be easy if it starts with things that are close to students. Local wisdom is one of the parts that are close to students and is not a new thing in their lives. A person's character will be formed from the closest environment, local wisdom as one of the legacies that contain many values that will form a strong character (Firza, 2016). Local wisdom is a strategy in the management of natural resources that have been tested in order to maintain security for humans and ecological balance (Fariannoor et al. 2013). Local wisdom is a view of life and science as well as a variety of life strategies in the form of activities carried out 
by local communities in answering various problems in meeting their needs (Fajarini, 2014).

Science learning requires students not only to have knowledge of science but also to apply that knowledge to solve problems in everyday life (Hairida and Junanto, 2018). Local wisdom-oriented learning gives more contextual impressions in learning, so students easily understand the material being studied (Jufridal et al., 2018). Through learning science-based on local wisdom, the process of discovery and verification in science is packaged in such a way that students are expected to not only master the scientific knowledge but can recognize and use the local wisdom of the society in managing the surrounding natural resources, so as to solve problems related with everyday life.

Local wisdom should be preserved and can be used in learning (Wahyuni, 2015). Implementation of character education through the values of local wisdom can improve national morality (Chairiyah, 2017). Students do not just understand and master the science concept, but the character and scientific literacy of students can also be improved through science learning based on local wisdom. Some research results are also shows there is an increase in character values through character-based learning Subali, Sopyan, and Ellianawati (2015) design science learning based on local wisdom (local wisdom) shows an increase in 11 positive characters of students, with the most significant positive characters honest characters, discipline, conscientious, diligent, cautious, responsible, and care about the environment. Sya'ban and Wilujeng (2016) developed a Specific Pedagogical Subject (SSP) in the form of syllabus, lesson plans, worksheets, teaching materials, and evaluation instruments in natural science learning using sources studying peatlands as a local superiority/local wisdom concluded an increase in the value of scientific literacy and concern for MTs students towards the environment.

Local wisdom in the society in Kubu Raya Regency is related to peatlands. The utilization of peatlands for agriculture and a source of social life in the Kubu Raya Regency has been done for a long time and has been carried on for generations. Initially, fertile peatlands became a source of food and provided benefits to prevent flooding and drought for society. However, in line with the expansion of food crop agriculture, settlement and land clearing for oil palm plantations, various peatland problems began to emerge. This needs to get serious attention from various parties, including educators. The role of educators is very important in developing students' mindsets (Hairida, 2017).

The results of a preliminary study (2019) on junior high school science learning in Kubu Raya Regency found that local wisdom or local superiority of peatlands as a source of learning has not been widely used by educators, although educators agree if local wisdom of peatlands is used as a source of learning. The results of the questionnaire given to junior high school science educators in the District of Kubu Raya were $81.82 \%$ of teachers agreeing to use the local wisdom of peatlands as a source of learning in science learning.
The Kubu Raya district's peatlands of around 523,400 or around 76 percent of the land in the Kubu Raya district contain local wisdom which is very potential to be a source of learning. Peatland farmers in Kalimantan basically already have a provision that has been handed down from generation to generation in managing peatlands (Prayoga, 2016). Peatland management technology that is appropriate to the nature and characteristics of the local ecosystem or local wisdom can be an alternative in managing peatlands (Ahmadi, 2017). So various natural resources with their ecosystems, agricultural products, activities and culture of the local society that become local wisdom of the people of Kubu Raya Regency can be packaged as sources or media through the development of learning tools. Development of teaching materials based on local wisdom as an effort to preserve local wisdom so that future generations can find out the local wisdom of their region (Rusilowati et al., 2015). Thus the local wisdom of the people of the District of Kubu Raya is maintained throughout the generations.

The people of Kubu Raya Regency are accustomed to using ash to grow crops on peatlands. Firmansyah and Mokhtar (2011) found that there was a custom of peatland farmers in Kalimantan to use ash or residual burning crops as soil fertility to grow crops on peatlands. Field burning activities are carried out in accordance with wind movement and carried out simultaneously so that all fields are burnt out and do not propagate anywhere. The habits of the people of Kubu Raya Regency in managing natural resources are important to be known and examined because they contain the concept of science and the value of character in it. This is very useful to be developed in science learning.

\section{MethodOLOGY}

The research method used was descriptive research, because the purpose of the study was to describe the local wisdom of the people of Kubu Raya Regency, especially those relating to peatlands which were used as a source of learning science and character education. The approach used in this research was qualitative research which produced descriptive data that described the behavior of the Kubu Raya district society in maintaining their lives. In addition, this study also described the behavior of junior high school science teachers in Kubu Raya Regency in learning science.

The study was conducted in the society and junior high schools in Kakap District, Sungai Raya District, Kubu District, Rasau Jaya District, and Sei Ambawang District in Kubu Raya Regency. The data collection was carried out in the field from May - September 2019. There were 10 teachers of natural science used as research subjects and 12 interviewed students from 5 (five) districts.

The data generated in the study in the form of questionnaire data and interviews with instrument triangulation techniques because it used more than one strategy to captured data. Direct data obtained from interviews with society leaders to find out the local wisdom of Kubu District, Sungai Kakap, Sungai Raya, Rasau Jaya, and Ambawang related businesses/work carried out by the society on peatlands. The selection of research sites was 
random because all districts in Kubu Raya Regency had peatlands.

The science teacher at a junior high school was interviewed to find out the learning methods used by the science teacher so far and his response to integrating local wisdom in science learning. Validation activities carried out on science teachers using a validation sheet that aimed to determine the teacher's response regarding the suitability of local wisdom findings with the Basic Competencies of junior high school science subjects. Students were interviewed about their responses to learning science that has been carried out by the teacher. Response questionnaires were also given to students to know their responses about learning science using local wisdom.

The semi-structured interviews of researchers with society leaders and farmers, science teachers, and students were conducted face-to-face, openly and flexibly. There were 5 society leaders interviewed from 5 districts (Kakap, Kubu, Sungai Raya, Batu Ampar, and Ambawang Districts). Farmer respondents were chosen randomly based on the type of crop the farmer worked on. There were 27 farmers interviewed in total, consisting of 15 rice farmers, 5 cassava farmers, sweet potatoes, taro, and corn, 2 rubber farmers, 2 coconut farmers, and 3 vegetable farmers. Farmer interview guidelines consisted of four questions, interviews with science teachers consisted of five questions, and interviews with students consisted of five questions. Students were also given a questionnaire in response to science learning that has been conducted by the teacher. The tools used in the interview were field notes, cameras, and audio records. Furthermore, the field findings data were analyzed descriptively and classified, and validated the relationship between the concepts of Natural Sciences and characters with the Basic Competencies of Science Curriculum Subjects in 2013 by 8 (eight) experts (junior high school science teachers). The complete research procedure is illustrated in Fig. 1.

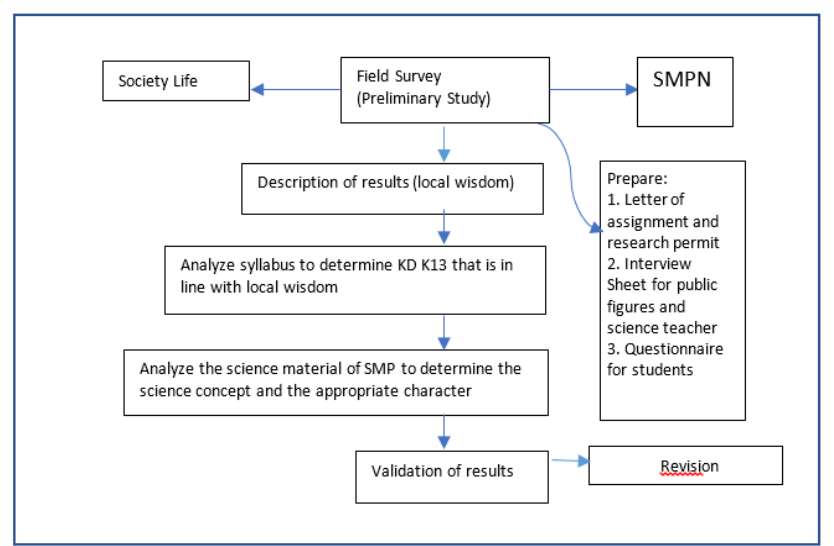

Fig. 1 Research Procedure

\section{RESULTS AND DISCUSSION}

In accordance with the purpose of the study to describe the local wisdom of the society of Kubu Raya Regency, the data collection activities were not only carried out on the life of the farming society but the data collection was also carried out in schools (teachers and students). This activity was carried out by a research team consisting of 2 lecturers, 1 teacher, and 4 students and began in May-September 2019. The research team conducted direct observations and interviews with social life in the Kubu Raya district.

Observations were made on the habits of society in maintaining their daily lives by utilizing peatlands. The results of observations obtained data that in addition to planting rice, farmers also plant other crops as interludes, for example, cassava, taro, corn, long beans. Some of the society also opened small businesses from the results of managing plants/vegetables on traditionally cultivated peatlands, such as making taro sticks, tapai, sweet potato and cassava chips, roasted corn. In detail, local wisdom found in the people of Kubu District, Sungai Kakap District, Sungai Raya District, and Sungai Ambawang District and Rasau Jaya District Kubu Raya Regency can be seen in Table I.

Culture or habits of the society in processing natural resources obtained from generation to generation from ancestors in the Kubu Raya Regency really need to be introduced to students in schools. Local wisdom can be used as a means of learning so that students understand and love the culture they have (Afiqoh, Atmaja, and Saraswati, 2018).

Integrating local wisdom can be done by educators in learning science. Students will be able to solve problems through integrated local wisdom in Natural Sciences (Mungmachon, 2012), be able to maintain the preservation of local wisdom and strengthen Indonesian identity with its various cultures, not only to understand concepts (Parmin, 2015), and become a source of student motivation to learn as well as bridging the formation of positive characters in students (Parwati, 2015). The results of identifying the suitability of local wisdom with the science concept of SMP and character values can be seen in Table II.

The analysis in Table II above showed that there were 7 (seven) $\mathrm{KD}$ in 7 th grade and 1 (one) $\mathrm{KD}$ in 8 th grade in the local wisdom of the Kubu Raya district society who used peatlands as a source of livelihood. Furthermore, the suitability validity of local wisdom with Basic Competencies, the concept of Sciences and character values carried out by 8 (eight) science teachers whose results can be seen in Table III.

TABLE III

SUITABILITY VALIDITY OF KD WITH LOCAL WISDOM, SCIENCE CONCEPTS, AND CHARACTER

\begin{tabular}{|c|c|c|c|c|c|c|c|c|c|}
\hline \multirow{2}{*}{ Validation Aspects } & \multicolumn{7}{|c|}{ Validator Score } & \multirow[b]{2}{*}{ Average } & \multirow[b]{2}{*}{ Criteria } \\
\hline & 1 & 2 & 3 & 45 & 56 & 67 & 78 & & \\
\hline $\begin{array}{l}\text { Suitability between } \mathrm{KD} \text { and Local } \\
\text { Wisdom }\end{array}$ & 4 & 4 & 4 & 4 & $4^{4}$ & 44 & $4 \quad 4$ & 4,00 & Valid \\
\hline $\begin{array}{l}\text { Suitability between local wisdom and the } \\
\text { Concept of Science }\end{array}$ & 4 & 4 & 4 & 4 & 44 & 44 & $4 \quad 4$ & 4,00 & Valid \\
\hline \multirow[t]{3}{*}{$\begin{array}{l}\text { Suitability between local wisdom and the } \\
\text { character values }\end{array}$} & 4 & 4 & 4 & 4 & 34 & 44 & $4 \quad 4$ & 3,88 & Valid \\
\hline & & & & & & & Total & 11,88 & \\
\hline & & & & & & verage S & Score & 3,96 & Valid \\
\hline
\end{tabular}

The results of the validation of 8 (eight) science teachers as validators obtained an average of 3.96 , so it was 
concluded that the compatibility between $\mathrm{KD}$ and local wisdom, local wisdom with the concept of science and local wisdom with character values was valid. Widoyoko (2012) states that the results of validation reaching more than 2.60 are said to be valid, although there are still things that need to be revised. Thus, local wisdom can social as a means in the design of science learning tools, for example, Lesson Plan (RPP), Student Worksheets (LKPD), learning media, and learning resources.

TABLE I

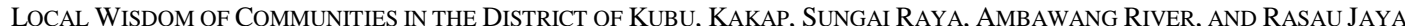

\begin{tabular}{cl}
\hline No & Observation Results of Local Wisdom \\
\hline 1. The culture in farming starts from farming, planting to harvesting. \\
2. The selection of charcoal raw materials from mangroves with selective cutting techniques based on the \\
3. Treement in the community. \\
4. Purityinally the processing of palm juice into brown sugar. \\
5. Adding slices of mangosteen tree bark, kawao root, young mangosteen rind, mangosteen leaves, and so on \\
6. Traditional copra processing. Drying is done using sunlight with a drying floor or shelves made of bamboo. \\
7. The habit of burning land to clear the remaining fields to grow rice \\
8. Farming by sprinkling ash from burning land and applying lime to the land to be planted. \\
9raditional processing in making various food preparations from various plants/vegetables in peatlands, for \\
9. example, corn, sweet potato, taro, coconut fruit, durian, suji leaves, pandanus and cassava into various chips, \\
10. Modol, traditional cakes, and tapai.
\end{tabular}

TABLE II

THE CONCEPTS OF SCIENCES AND CHARACTER VALUES OF SOCIETY LOCAL WISDOM IN KUBU RAYA REGENCY

\begin{tabular}{|c|c|c|c|}
\hline Basic Competences & Local Wisdom & Science Concepts & Character Values \\
\hline $\begin{array}{l}\text { 7th grade } \\
\text { 3.2. Classifying living things and objects } \\
\text { based on observed characteristics }\end{array}$ & $\begin{array}{l}\text { Farming by sprinkling ash from burning } \\
\text { land and lime on the land to be planted. }\end{array}$ & Alkaline Acid & $\begin{array}{l}\text { 1. Creative } \\
\text { 2. Diligent } \\
\text { 3. Cooperation }\end{array}$ \\
\hline
\end{tabular}

4.2. Present the results classification of creatures life and objects in the surrounding environment based on the observed characteristics

7 th grade

3.3. Explain the concept of mixtures and single substances (elements and compounds), physical and chemical properties, physical and chemical changes in life daily

4.3. Present the results of investigations or works about the nature of the solution, physical changes, and chemical changes, or the separation of the mixture

7 th grade

3.4. Analyzing the concepts of temperature, expansion, heat, heat transfer, and its application in everyday life including the mechanism of maintaining stable body temperature in humans and animals

7 th grade

3.8. Analyzing the occurrence of environmental pollution and its impact on the ecosystem

4.8. Making writings about the idea of solving pollution problems in the environment based on observations

1. Purifying peat water when drought for daily needs

2. Making tapai from cassava

3. The selection of charcoal raw materials from mangroves with selective cutting techniques based on the agreement in society.
1. Mixtures

2. Changes in physics and chemistry
1. Curiosity

2. Careful

3. Cooperation

4. Environmental Care
1. Traditionally processing palm water into brown sugar

2. Traditional copra processing. Drying is done using sunlight with a drying floor or shelves made of bamboo

1. The habit of burning land to clean up the remaining fields to plant rice.

2. The selection of charcoal raw materials from mangroves with selective cutting techniques based on the agreement in the
1. Characteristics of 1. Cooperation Things

2. Change in form

2. Creative

3. Diligent

4. Responsibility
Environmental pollution
1. Environmental care

2. Cooperation

3. Responsibility

4. Answer

5. Attention

6. Creative

7. Careful 


\begin{tabular}{|c|c|c|c|}
\hline Basic Competences & Local Wisdom & Science Concepts & Character Values \\
\hline & community. & & $\begin{array}{ll}\text { 8. } & \text { Conscientious } \\
\text { 9. } & \text { Diligent }\end{array}$ \\
\hline \multicolumn{4}{|l|}{ 8th grade } \\
\hline $\begin{array}{l}\text { 3.6. Explain various additives in food and } \\
\text { drinks, addictive substances, and } \\
\text { their impact on health }\end{array}$ & $\begin{array}{l}\text { 1. Adding pieces or slices of } \\
\text { mangosteen bark, roots kawao, } \\
\text { young mangosteen rind, } \\
\text { mangosteen leaf, and so on before }\end{array}$ & Natural additives & $\begin{array}{ll}\text { 1. } & \text { Creative } \\
\text { 2. } & \text { Conscientious } \\
\text { 3. } & \text { Careful } \\
\text { 4. } & \text { Diligent }\end{array}$ \\
\hline $\begin{array}{l}\text { 4.6. Making a paper about the effects of } \\
\text { the abuse of additives and addictive } \\
\text { substances for health }\end{array}$ & $\begin{array}{l}\text { the wiretapping is done in the sap } \\
\text { room } \\
\text { Traditional processing in making } \\
\text { various food from various } \\
\text { plants/vegetables in peatlands, for } \\
\text { example, corn, sweet potato, taro, } \\
\text { suji leaves, pandanus, coconuts, } \\
\text { and cassava into various chips, } \\
\text { dodol, cakes-Traditional cake, } \\
\text { tapai. }\end{array}$ & & 5. Environmental Care \\
\hline $\begin{array}{l}\text { 9th grade } \\
4.8 \text { Present the results of the } \\
\text { investigation, ideas or the search } \\
\text { for information about the } \\
\text { application of biotechnology in } \\
\text { supporting the continuity of human } \\
\text { life through food production. }\end{array}$ & Making tempoyak, tempeh, and tapai & $\begin{array}{l}\text { Conventional } \\
\text { Biotechnology }\end{array}$ & $\begin{array}{ll}\text { 1. } & \text { Creative } \\
\text { 2. } & \text { Conscientious } \\
\text { 3. } & \text { Careful }\end{array}$ \\
\hline
\end{tabular}

\section{CONCLUSIONS AND SUGGESTIONS}

In accordance with the results of the research that has been carried out, it can be concluded that the local wisdom of the Kubu Raya Regency society related to peatlands can be implemented in the science learning tools in junior high schools in the form of Lesson Plan (RPP), Students Worksheets (LKPD), and science supplements. The number of $\mathrm{KD}$ in science subjects that are in accordance with local wisdom consists of 7 (seven) $\mathrm{KD}$ in 7 th grade, 2 (two) $\mathrm{KD}$ in 8th grade, and 1 (one) KD in 9th grade. Through the results of the study, the teachers can implement local wisdom in the science learning tool and carried out science learning in the class to preserve the local wisdom and to develop students' character.

\section{REFERENCES}

Afiqoh, N., Atmaja, H.T., Saraswati, U. (2018). Penanaman Nilai Kearifan Lokal dalam Pembelajaran Sejarah Pokok Bahasan Perkembangan Islam di Indonesia Pada Siswa Kelas X IPS di SMA Negeri 1 Pamotan Tahun Ajaran 2017/2018. Indonesian Journal of History Education, 6(1), 42-53.

Ahmadi, T.T. (2017). Pengelolaan Sumberdaya Lahan Gambut di Kubu Raya Kalimantan Barat Menuju Lahan Tanpa Bakar. Jurnal AGROSAMUDRA, 4(2), 92-109.

Alawiyah, F. (2012). Kebijakan dan Pengembangan Pembangunan Karakter Melalui Pendidikan di Indonesia. Jurnal Aspirasi, 3(1), 87-101.

Chairiyah. (2017). Implementasi Pendidikan Karakter Melalui Nilai-Nilai Kearifan Lokal di SD Taman Siswa Jetis Yogyakarta. Trihayu: Jurnal Pendidikan Ke-SD-an, 4(1), 208-215.
Dirgantoro, A. (2016). Peran Pendidikan dalam Membentuk Karakter Bangsa Menghadapi Era Masyarakat Ekonomi Asean (MEA). Jurnal Rontal Keilmuan PPKn, 2(1), 1-7.

Fajarini, U. (2014). Peranan Kearifan Lokal dalam Pendidikan Karakter. Sosio Didaktika, 1(2).

Fariannoor, W. T., Taharuddin, M. R. Maryono. (2013). The Practice of Local Wisdom of Dayak People in Forest Conservation in South Kalimantan. Indonesian Journal of Wetlands Environmental Management, 1(1).

Firmansyah, M. A. and Mokhtar, M. S. (2011). Kearifan Lokal Pemanfaatan Lahan Gambut untuk Usahatani dalam Mengantisipasi Dampak Perubahan Iklim di Kalimantan Tengah. Makalah Workshop Nasional Adaptasi Perubahan Iklim di Sektor Pertanian. Bandung.

Firza. (2016). Local Wisdom Sebagai Dasar Dalam Pembentukan Karakter. Prosiding Seminar Nasional Reforming Pedagogy, 361-365.

Hairida and Junanto, T. (2018). The Effectiveness of Performance Assessment in Project-Based Learning by Utilizing Local Potential to Increase Science Literacy. International Journal of Pedagogy and Teacher Education, 2, 151-162.

Hairida. (2017). Using Learning Science, Environment, Technology and Society (SETS) Local Wisdom and based Colloids Teaching Material. Journal of Education, Teaching and Learning, 2(1), 143-148.

Jufridal, Basuki, F. R., and Rahma, S. (2018). Potensi Kearifan Lokal Geopark Merangin sebagai Sumber Belajar Sains di SMP. Jurnal Edufisika, 3(1), 1-16. 
Listyarti, R. (2012). Pendidikan Karakter dalam Metode Aktif, Inovatif, dan Kreatif. Jakarta: Penerbit Erlangga.

Masrukhi. (2012). Membangun Karakter Mahasiswa Berbasis Nilai Konservasi. Indonesian Journal of Conservation, 1(1), 20-29.

Mawardi, I. (2012). Pendidikan Life Skills Berbasis Budaya Nilai-nilai Islami dalam Pembelajaran. Jurnal Pendidikan Islam, 6(2), 216-228.

Mungmachon, M. R. (2012). Knowledge and local wisdom: Society treasure. International Journal of Humanities and Social Science, 2(13), 174-181.

Parmin, Sajidan, Ashadi, and Sutikno. (2015). Skill of Prospective Teacher in Integrating the Concept of Science with Local Wisdom Model. Indonesian Journal of Science Education, 4(2), 120-126.

Parwati. (2015). Pengembangan Model Pembelajaran Pemecahan Masalah Berorientasi Kearifan Lokal Pada Siswa SMP di Kota Singaraja. Jurnal Pendidikan Indonesia, 4(2).

Prayoga, K. (2016). Pengelolaan Lahan Gambut Berbasis Keraifan Lokal di Pulau Kalimantan. Prosiding Seminar Nasional Lahan Basah Jilid 3 Lembaga
Penelitian dan Pengabdian kepada Masyarakat. Universitas Lambung Mangkurat.

Rusilowati, A., Supriyadi, and Widiyatmoko, A. (2015). Pembelajaran Kebencanaan Alam Bervisi SETS Terintegrasi dalam Mata Pelajaran Fisika Berbasis Kearifan Lokal. Jurnal Pendidikan Fisika Indonesia, 11(1), 42-48.

Subali, B., Sopyan, A., \& Ellianawati, E. (2015). Developing local wisdom based science learning design to establish positive character in elementary school. Jurnal Pendidikan Fisika Indonesia, 11(1), 1-7.

Sya'ban, M. F. and Wilujeng, I. (2016). Pengembangan SSP Zat dan Energi Berbasis Keunggulan Lokal untuk Meningkatkan Literasi Sains dan Kepedulian Lingkungan. Jurnal Inovasi Pendidikan IPA, 2(1), 66-75.

Wahyuni, S. (2015). Developing Science Learning Instruments Based on Local Wisdom to Improve Students' Critical Thinking Skills. Jurnal Pendidikan Fisika Indonesia, 11(1), 1-7.

Widoyoko, E. P. (2016). Teknik-Teknik Penyusunan Instrumen Penelitian. Yogyakarta: Pustaka Pelajar. 